AGRARIS: Journal of Agribusiness and Rural Develpoment Research

Vol. 4 No. 2 Juli-Desember 2018
I Made Yoga Prasada*, Aura Dhamira, Agus Dwi Nugroho

Program Studi Ekonomi Pertanian, Fakultas Pertanian Universitas Gadjah Mada

*) e-mail korespondensi: imade.yogap@gmail.com

\section{Supply Response of Paddy in East Java: Policy Implications to Increase Rice Production}

DOI: http://dx.doi.org/10.18196/agr.4268

\begin{abstract}
An increasing population in recent decades has led to the need for increasing the availability of food, so it is necessary to increase the production of paddy as quickly as possible. The aim of this research was to know the supply response of paddy in East Java to various price factors and non-price factors. In this research, the supply response was estimated by the paddy harvest areas in East Java using CobbDouglas model and Nerlove partial adjustment, and econometric analysis including stationarity test, cointegration test, and Error Correction Model (ECM). The data used in this research consisted of paddy harvest areas, grain price, corn price, irrigated land area and rainfall amount from 1991 to 2015. The speed of short-term adjustment to the longterm supply of rice was $2.79 \%$ and was corrected in the next period. In the short run, all variables did not have a high responsiveness to paddy supply, but in the long run, the irrigation area was very responsive to paddy supply in East Java with a value of elasticity of 1.79. Supply of paddy can be increased by increasing the real price of unhulled rice, the irrigated land, and harvested area of the previous period.
\end{abstract}

Keywords: East Java, elasticity, paddy, response, supply commodities export demand from China. In addition, Indonesian agricultural commodities export demand tend to increased despite the export prices of agricultural commodities and import tariffs of agricultural commodities in China increased.

Keywords: agricultural commodities, export demand, panel data

\section{INTRODUCTION}

Paddy is one of the most important food commodities in Indonesia. Paddy can produce staple food for most of Indonesia's population in the form of rice. Therefore, the existence of paddy becomes a very crucial thing to be studied. The availability of paddy in the community depends heavily on paddy production at the farm level. East Java Province is one of the paddy production centers and become the first position before West Java Province as the largest paddy producer in Indonesia. East Java Province was capable of producing dry milled unhulled rice with the average of $10,460,278$ tons per year from 2001 to 2015 with an increase in production of $0.52 \%$. The additional production was greater compared to that of West Java in the period of the same year which only reached the level of $0.23 \%$ (BPS, 2016). In addition, the data obtained from Indonesian Central Bureau of Statistics also showed that the vast paddy harvest in East Java increased by $0.45 \%$ from 1991 to 2015 .

The harvest area for paddy commodities in East Java Province fluctuated from year to year. However, the harvest area for this commodity tends to increase, especially during the period of 2011 to 2015. The harvest area in 2015 even reached 2,152,070 hectares. The increase in the harvested area is due to the support from the government in the form of "Peningkatan Produksi Beras Nasional (P2BN)" or National Paddy Production Enhancement program and the optimization and expansion of agricultural land to achieve food self-sufficiency (Garside \& Asjari, 2015).

Increasing the area of paddy harvest and production in East Java is very important to be done in order to balance the increasing demand 
for food consumption of the Indonesia's population following the increase in population (Ayu \& Pramesty, 2016; Partini et al., 2013; Widodo \& Wulandari, 2016). The rate of the population growth in Indonesia averaged $1.36 \%$ per year in 2010 to 2016, whereas paddy production in Indonesia only had a growth rate of $0.02 \%$ per annum over the same period (BPS, 2016). This shows that there has been an imbalance between paddy supply and demand for paddy commodities in Indonesia with a constant food consumption in Indonesia. Therefore, paddy supply needs to be increased, especially in East Java province as the center of paddy production, so that the demand for staple food in Indonesia can be fulfilled well. Paddy supply in East Java can be increased by knowing the supply response of paddy in East Java to various factors influencing it, both paddy and non-paddy factors (Khan et al., 2018; Shahzad et al., 2018) .

Some studies on paddy supply response have been conducted. A study in Kediri showed that the supply response of paddy harvest area to the area of paddy harvest in the previous year was inelastic in the short and long run (Choirina et al., 2016), while the supply response of local rice in Nigeria indicated that in the short-run supply response of local rice production to the expected price of local rice and area planted with local rice was inelastic, but in the longrun it became elastic (Rahji \& Adewumi, 2008). Another study was conducted concerning the supply response of maize in Pakistan (Khan et al., 2018). This study concluded that the short-run supply response of maize production is inelastic to maize production in the previous year, rice price, and maize price and in the long-run supply response of maize production to maize production in the previous year was elastic, but to rice price and maize price was inelastic.

Some models have been used on the supply response study. Supply response can be approached by using the harvested area of a commodity. The research in Kediri used an approach to harvest area of paddy to determine the supply response of rice (Choirina et al., 2016). The study used the variables of price of rice, fertilizer price index, rainfall, rice harvest area at 1, 2 and 3 years earlier. In addition, the research in Nigeria used planting area variable, and the expected local rice prices to determine the supply response of local rice (Rahji \& Adewumi, 2008). The research in Pakistan related to the supply response of maize used the variables of corn production in the previous year, corn prices, and rice prices as the independent variables in the model (Khan et al., 2018).

However, these studies did not use the Error Correction Model (ECM) approach, therefore, the relationship between short run and long run equilibrium of the model remained unknown. This research tried to estimate using the Error Correction Model (ECM) method as an approach to find out about the supply response of paddy in East Java in short and long run with different variables in the model. The purposes of this study were to 1) determine the balance adjustment of the model of paddy supply and the factors that affected the paddy supply in the short-run and long-run, and 2) determine the supply elasticity of variables in the model in the short and long run.

\section{METHODS}

The data used in this research were secondary data which included extensive paddy harvesting data, real price of unhulled rice, real price of corn, irrigated land area, and precipitation from 1991 to 2015 in the province of East Java. These data were obtained from the publication of the Indonesian Central Bureau of Statistics (BPS). The supply response was estimated through the area of paddy harvest in East Java using Cobb-Douglas model and Nerlove partial adjustment, as well as econometric analysis (stationarity test, cointegration, and Error Correction Model).

The supply response or product of an agricultural commodity including paddy to both price and non-price factors requires a grace period, or the so-called time lag. In the short run, changes in price factors or other factors cannot be immediately responded by farmers, especially when farmers are doing production activities. This occurs because agricultural activities, including paddy farming takes time biologically. Therefore, Nerlove partial model was used to estimate the time lag variable that appearred in the model. This model will calculate the 
elasticity of the area of paddy harvest $\left(A_{t}^{d}\right)$ in this case the variables used were the real price of unhulled rice in year $r\left(\mathrm{P}_{t}\right)$, real price of corn $\left(\mathrm{P}_{c_{t}}\right)$, irrigated land area $\left(I_{t}\right)$, rainfall $\left(R_{t}\right)$, the area of paddy harvest in the previous year $\left(A_{t-1}^{d}\right)$ and a vector estimated in this equation $(\beta)$. Nerlove partial model used in this study is as follows:

$$
A_{t}^{d}=\beta_{0}+\beta_{1} P_{t}+\beta_{2} P_{c_{t}}+\beta_{3} I_{t}+\beta_{4} R_{t}+\beta_{5} A_{t-1}^{d}+\varepsilon_{t}
$$

The Nerlove partial model was then transformed in the form of the Cobb-Douglas linear equation as follows:

$$
\operatorname{Ln} A_{t}^{d}=\operatorname{Ln} \beta_{0}+\beta_{1} \operatorname{Ln} P_{t}+\beta_{2} \operatorname{LnP}_{c_{t}}+\beta_{3} \operatorname{LnI}_{t}+\beta_{4} \operatorname{LnR}_{t}+\beta_{5} \operatorname{Ln} A_{t-1}^{d}+\varepsilon_{t}
$$

Based on the Cobb-Douglas model, the short run elasticity of each variable from the independent variables can be seen from the coefficients of regression of each variable. The regression coefficient in the model was done by $t$ test to determine the level of significance in the variables used (Denziana et al., 2014). The long run elasticity (LRE) can be determined by using the following equation:

\section{Long-Run Elasticity $(\mathrm{LRE})=$ Short-run Elasticity $/\left(1-\beta_{5}\right)$}

The analysis using time series data usually requires a stationary test to ensure the validity of the process. The stationarity test in this research was conducted by using Augmented Dickey Fuller test (ADF). This test was done by doing augmentation to the equation by adding the value that affected the time interval to variable $\Delta$ Yt (Gujarati, 2004). The $\mathrm{ADF}$ test was performed by estimating the following equations:

$$
\Delta \mathrm{Y}_{\mathrm{t}}=\beta_{1}+\beta_{2}+\delta \mathrm{Y}_{\mathrm{t}-1}+\sum_{\mathrm{i}=1}^{\mathrm{m}} \alpha_{1} \Delta \mathrm{Y}_{\mathrm{t}-1}+\varepsilon_{\mathrm{t}}
$$

Where $\varepsilon t$ is the error rate of 'white noise' and where $\Delta \mathrm{Yt}-1=(\mathrm{Yt}-1-\mathrm{Yt}-2), \Delta \mathrm{Yt}-2=(\mathrm{Yt}-2-\mathrm{Yt}-3)$ and so on. The amount of lag difference entered is often empirically determined, this is done in order to the error rate does not have a serial correlation. The ADF is tested when the $\delta=0$ and the ADF test follows the same asymptotic distribution with DF statistics, so the same critical value can be used. To make a decision, comparing the computed ADF value with the MacKinnon critical values is needed for the rejection of a hypothesis for a unit root. If the computed $\delta$ (ADF) statistic is less negative (that is, lies to the right of MacKinnon critical values) relative to the critical values, the null hypothesis of non-stationarity in time series available is not rejected. If the null hypothesis is rejected, then the time series data is stationary, hence no unit root (Dziwornu \& Vitor, 2013).

In this study we also conducted Error Correction Model (ECM) testing and cointegration test. ECM is an analysis of time series data that is generally used for variables that usually have some kind of dependency. The ECM method is used to balance short run economic relationships of variables that already have long run economic balance (Muhammad, 2014). Meanwhile, the cointegration test between variables aims to see the relationship or balance in the long run between independent variables and dependent variable (Akbar et al., 2016). The co-integration test was carried out using the Johansen Co-integration Test by comparing the trace statistic and maximum eigenvalue values. If the trace statistic and maximum eigenvalue values are greater than the critical value at $5 \%$, this shows the occurrence of co-integration in the model used (Atmaja et al., 2015). However, in the short run there is the possibility of an imbalance between variables, thus requiring analysis or testing Error Correction Model (ECM) . The model used to perform this ECM test is as follows:

$$
\Delta \mathrm{A}_{\mathrm{t}}^{\mathrm{d}}=\beta_{0}+\beta_{1} \Delta \mathrm{P}_{\mathrm{t}}+\beta_{2} \Delta \mathrm{P}_{\mathrm{ct}_{\mathrm{t}}}+\beta_{3} \Delta \mathrm{I}_{\mathrm{t}}+\beta_{4} \Delta \mathrm{R}_{\mathrm{t}}+\gamma \mathrm{e}_{\mathrm{t}-1}+\mathrm{v}_{\mathrm{t}}
$$

The $\Delta$ symbol is used for differentiated variables. Where $\Delta \mathrm{A}_{t}^{\mathrm{d}}$ is the differentiated area of paddy harvests, $\Delta \mathrm{P}_{\mathrm{t}}$ is differentiated real unhulled rice price in the year $t, \Delta \mathrm{P}_{\mathrm{c}_{\mathrm{t}}}$ is the differentiated real price of corn, $\Delta \mathrm{I}_{\mathrm{t}}$ is the differentiated area of irrigated land and $\Delta R_{t}$ is a differentiated rainfall variable. Meanwhile, et- 1 is the residual or long run equation error in period $t-1$ and vt is an error in the short-run equation. 
Coefficient $\gamma$ in the above equation is also often referred to as the speed of adjustment which is the residual/error velocity (e) in the previous period to correct the change of the dependent variable to the balance in the next period. There is a final requirement that must be met in this stage, coefficient $\gamma$ must be significant and negative.

\section{RESULTS AND DISCUSSION}

The data used in this study included the area of paddy harvest, unhulled rice prices, the price of corn, irrigated land area, rainfall and paddy harvest area lag 1. All variables used in this study should be spared from their units root at each variable, so we did stationarity test using ADF method (Augmented Dickey-Fuller) unit root test (Ayinde et al., 2017).

TABLE 1. RESULTS OF STATIONARITY TEST AT STAGE LEVEL

\begin{tabular}{lcrrrl}
\hline \multirow{2}{*}{ Variables } & ADF & \multicolumn{3}{c}{ MacKinnon Critical Value } & \multirow{2}{*}{ Information } \\
\cline { 3 - 5 } & Statistics & $\mathbf{1 \%}$ & $\mathbf{5 \%}$ & $\mathbf{1 0 \%}$ & \\
\hline Harvest Area $\left(\mathrm{A}_{\mathrm{t}}\right)$ & 0.9093 & -3.7529 & -2.9981 & -2.6388 & \multirow{2}{*}{ Not Stationary } \\
Rainfall $\left(\mathrm{R}_{\mathrm{t}}\right)$ & -1.2715 & -3.7379 & -2.9919 & -2.6355 & Not Stationary \\
Real Price of Paddy $\left(\mathrm{P}_{\mathrm{t}}\right)$ & -0.7575 & -3.7379 & -2.9919 & -2.6355 & Not Stationary \\
Area of Irrigation $\left(\mathrm{l}_{\mathrm{t}}\right)$ & -1.3701 & -3.7529 & -2.9981 & -2.6388 & Not Stationary \\
Real Corn Price $\left(\mathrm{P}_{\mathrm{ct}}\right)$ & -1.3069 & -3.7379 & -2.9919 & -2.6355 & Not Stationary \\
Harvest Area Lag 1 $\left(\mathrm{A}_{\mathrm{t}-1}\right)$ & 0.6244 & -3.7529 & -2.9981 & -2.6388 & Not Stationary \\
\hline Source: Secondary Data Analysis $(2018)$ & & & &
\end{tabular}

All the variables used in this study were not stationary at the level stage as shown in Table 1 . This is shown by the ADF statistic value which is greater than the value of MacKinnon Critical Value, so that the null hypothesis stating that there is no unit root in each variable failed to be rejected. It is necessary to do unit root test in the first difference level to the nonstationary variables.

TABLE 2. RESULTS OF STATIONARITY TEST AT FIRST DIFFERENCE LEVEL

\begin{tabular}{|c|c|c|c|c|c|}
\hline \multirow{2}{*}{ Variables } & \multirow{2}{*}{$\begin{array}{c}\text { ADF } \\
\text { Statistic } \\
\mathbf{s} \\
\end{array}$} & \multicolumn{3}{|c|}{ MacKinnon Critical Value } & \multirow{2}{*}{$\begin{array}{c}\text { Informatio } \\
n\end{array}$} \\
\hline & & $1 \%$ & $5 \%$ & $10 \%$ & \\
\hline Harvest Area $\left(A_{t}\right)$ & -6.9221 & -3.7529 & -2.9981 & -2.6388 & Stationary \\
\hline Rainfall $\left(R_{t}\right)$ & -9.5857 & -3.7529 & -2.9981 & -2.6388 & Stationary \\
\hline Real Price of Paddy $\left(P_{t}\right)$ & -4.3921 & -3.7529 & -2.9981 & -2.6388 & Stationary \\
\hline Area of Irrigation $\left(\mathrm{I}_{\mathrm{t}}\right)$ & -4.4021 & -3.7529 & -2.9981 & -2.6388 & Stationary \\
\hline Real Corn Price $\left(P_{c t}\right)$ & -5.2857 & -3.7529 & -2.9981 & -2.6388 & Stationary \\
\hline Harvest Area Lag $1\left(\mathrm{~A}_{\mathrm{t}-1}\right)$ & -7.0548 & -3.7529 & -2.9981 & -2.6388 & Stationary \\
\hline
\end{tabular}

All the data at the first difference level was stationary (Table 2). It is characterized by ADF statisic value which is smaller than the value of MacKinnon Critical Value. The data that were already stationary at the first difference level showed that the data which had been used avoided non-stationary behavior.

\section{DATA COINTEGRATION TEST}

Cointegration test is conducted to determine whether there is a long run relationship of a system of equations. If a system of equations has a long run relationship, it means that the equation has mutually
TABLE 3. JOHANSEN COINTEGRATION TEST RESULTS

\begin{tabular}{lrrrr}
$\begin{array}{c}\text { Hypothesized } \\
\text { No. of CE (s) }\end{array}$ & Eigenvalue & $\begin{array}{c}\text { Trace } \\
\text { Statistic }\end{array}$ & $\begin{array}{c}\text { Critical } \\
\text { Value } \\
\mathbf{0}\end{array}$ & Prob. ${ }^{* *}$ \\
\hline None * & 0.9804 & 164.3693 & 69.8189 & 0.0000 \\
At most 1 * $^{*}$ & 0.9131 & 77.8461 & 47.8561 & 0.0000 \\
At most 2 & 0.5490 & 24.1024 & 29.7971 & 0.1961 \\
At most 3 & 0.2580 & 6.5865 & 15.4947 & 0.6262 \\
At most 4 & 0.0010 & 0.0211 & 3.8415 & 0.8845 \\
\hline Source: Secondary Data Analysis (2018) & &
\end{tabular}

credited variables, so it can be interpreted that the equations used will have a long run equilibrium 
(Muhammad, 2014; Okon \& Sunday, 2014). Cointegration test can be done using Johansen Cointegration method which uses trace statistic value compared with value of trace (Akanni and Okeowo, 2011).

The trace statistic is greater than the critical value in two equations with an error term of $5 \%$ as shown in Table 3. This indicates that there are two equations which have mutual cointegration variables. The equation has mutually cointegrated variables, indicating that there is long-run equilibrium between each of the variables used.

\section{BALANCE ADJUSTMENT AND FACTORS AFFECTING PADDY SUPPLY IN THE SHORT- RUN AND THE LONG-RUN IN EAST JAVA}

Equations with long run equilibrium need to be analyzed using error correction model to determine if there is an adjustment from short run to long run on the results of estimation made. The occurrence of adjustments in the short run to the long run can be seen from the coefficient of error correction vector (ECM) if the value is negative and significant (Ehirim $\&$ Owerri, 2017). To estimate the factors influencing paddy supply in East Java, Cobb-Douglas model was used.

TABLE 4. FACTORS AFFECTING THE SUPPLY OF PADDY IN THE SHORT RUN IN EAST JAVA

\begin{tabular}{lccc}
\hline Variable & Coefficient & t-Statistic & Prob. \\
\hline C & $0.012838^{* *}$ & 2.477233 & 0.0240 \\
Rainfall $\left(\mathrm{R}_{\mathrm{t}}\right)$ & $-0.019665^{\mathrm{ns}}$ & -1.679049 & 0.1114 \\
Real Unhulled rice Price $\left(\mathrm{P}_{\mathrm{t}}\right)$ & $0.094171^{* *}$ & 2.329110 & 0.0324 \\
Area of Irrigation $\left(\mathrm{I}_{\mathrm{t}}\right)$ & $0.589781^{\mathrm{ns}}$ & 1.496949 & 0.1527 \\
Harvest Area Lag 1 $\left(\mathrm{A}_{\mathrm{t}-1}\right)$ & $0.097834^{\mathrm{ns}}$ & 0.861536 & 0.4009 \\
Real Corn Price $\left(\mathrm{P}_{\mathrm{ct}}\right)$ & $-0.006000^{\mathrm{ns}}$ & -0.197697 & 0.8456 \\
Error Correction & $-0.027877^{* *}$ & -2.341304 & 0.0421 \\
\hline R-squared & 0.823004 & & \\
Adjusted R-squared & 0.760535 & & \\
F-statistic & 13.17460 & & \\
Prob . (F-statistic) & 0.000014 & & \\
\hline Source: Seconday Data Analysis & $2018)$ & &
\end{tabular}

Source: Secondary Data Analysis (2018) Information:

*** $=$ Significant at $99 \%$ confidence level $(\mathrm{t}$-count $=2.84)$

** = Significant at 95\% confidence level $(\mathrm{t}-$ count $=2.09)$

* $\quad=$ Significant at $90 \%$ confidence level $(t-$ count $=1.72)$

$=$ Significant at $90 \%$
$=$ Not significant
The value of error correction vector (ECM) was -0.0279 (Table 4), the value was significant at the error rate of 5\%. The ECM value obtained showed a negative value and significant, which means that there is a short run to long run adjustment to the paddy supply in East Java. The ECM coefficient was 0.0279, meaning that the speed of adjustment from the shortterm balance to the long-term balance of the rice supply in East Java to the change of rainfall, the price of real grain, irrigated land area, harvest area lag 1 , and the real price of corn was $2.79 \%$. Short run to long run full adjustment (100\%) for the paddy supply in East Java takes a long time. This value is included in the category of slow adjustment speed, because it is worth less than $50 \%$. A research about agricultural response to the price and exchange rate in Nigeria showed ECM values of $85.91 \%$ (Obayelu \& Sheu, 2010), while another research in Nigeria about errorcorrection modelling of agricultural output showed ECM values of $61.28 \%$ (Ngbede et al., 2009). Those researches illustrates the occurrence of a high-speed adjustment of long-term balance against changes in variables in the model used. The slow adjustment of the rice supply in East Java can be caused due to the low level of stimulation provided to increase the paddy supply in East Java, stimulating the increase in unhulled rice prices at the farmer level, expansion of irrigated area, and expansion of harvest area lag 1 (previous year period). The price of unhulled rice in the farmers' level highly fluctuated after deflated by the producer price index. This causes the speed of the short run to long run balance adjustment to be slower, on the contrary if the price of unhulled rice at the farmer level consistently increases, then the speed of the short run to long run balance adjustment can also be accelerated. The irrigated land area variable also showed the same thing, namely land area irrigated from 1991 to 2015 decreased by an average of $0.01 \%$ per year, causing slower balance adjustment from the short run to the long run.

There is only one variable that influences the supply of paddy harvest area in East Java in the shortrun as shown in Table 4, that is the variable of real unhulled rice price at the farmer level. This is because it takes time (time lag) to see any reaction from a 
variable while another variable changes, so that in the short run there are not many variables that can influence the paddy supply in East Java. In the short run, the variable of real unhulled rice price had an effect on the paddy supply in East Java at 5\% error rate with a coefficient value 0.094 . The coefficient value means that the paddy supply in East Java will increase by $0.094 \%$ everytime there is an increase in the real unhulled rice prices by $1 \%$ in the short run. The analysis of factors affecting the paddy supply in East Java in the short run showed a little difference in the long run. In the long run, there were more variables that significantly affected the paddy supply in East Java.

TABLE 5. FACTORS AFFECTING LONG RUN PADDY SUPPLY IN EAST JAVA

\begin{tabular}{lccc}
\hline Variable & Coefficient & t-Stati & Prob. \\
\hline Constant & $-5.237753^{\text {ns }}$ & -0.90467 & 0.3770 \\
Rainfall $\left(\mathrm{R}_{\mathrm{t}}\right)$ & $-0.024561^{\mathrm{ns}}$ & -0.72664 & 0.4763 \\
Real Unhulled rice Price $\left(\mathrm{P}_{\mathrm{t}}\right)$ & $0.146820^{* *}$ & 2.44987 & 0.0242 \\
Area of Irrigation $\left(\mathrm{I}_{\mathrm{t}}\right)$ & $0.770185^{*}$ & 1.77901 & 0.0912 \\
Harvest Area Lag 1 $\left(\mathrm{A}_{\mathrm{t}-1}\right)$ & $0.570652^{* * *}$ & 2.90397 & 0.0091 \\
Real Corn Price $\left(\mathrm{P}_{\mathrm{ct}}\right)$ & $-0.00276^{\mathrm{ns}}$ & -0.06157 & 0.9516 \\
\hline R-squared & 0.866458 & & \\
Adjusted R-squared & 0.831315 & & \\
F-statistic & 24.65543 & & \\
Prob . (F-statistic) & 0.000000 & & \\
\hline Source: Seconday Dat Analysi & $2018)$ & & \\
\hline
\end{tabular}

Source: Secondary Data Analysis (2018)

Description :

*** = Significant at $99 \%$ confidence level $(\mathrm{t}$-count $=2.84)$

* $\quad=$ Significant at $95 \%$ confidence level ( $\mathrm{t}-\mathrm{count}=2.09$ )

* $\quad=$ Significant at $90 \%$ confidence level $(t-$ count $=1.72)$

$=$ Not significant

Three factors that influence the paddy supply in East Java are presented in table 5, which are real price factor of unhulled rice at the farmer level $(\mathrm{Pt})$, irrigated land area (It), and harvested area of paddy lag 1 (At-1). The price of unhulled rice had a coefficient value of 0.147 and was significant at a 5\% error rate. These results indicated that the higher the price of unhulled rice at the farmer level, the higher the area of harvest. Rising unhulled rice prices at the farmer level of $1 \%$ can increase the supply of paddy harvest area by $0.147 \%$. Increasingly higher prices at the farmer level indicates that the incentives received by farmers from their paddy farming activities become greater (Purbiyanti et al., 2017). Higher incentives received by farmers can increase the supply of paddy harvest area in East Java. Related to the real price of unhulled rice at the farmer level, the variable of irrigated land area also had a significant effect with a coefficient equal to 0.770 . The coefficient means that an increase in irrigated land area of $1 \%$ can increase the area of a real harvest of paddy by $0.770 \%$. The area of irrigated land becomes very important because it affects the supply of paddy harvest area because most of the paddy cultivated in Indonesia requires adequate water availability. The need for water in paddy cultivation has to be considered well, so that the stem irrigation can be done optimally and the growth and production of paddy crops can be boosted as optimally as possible (Yanti \& Pratama, 2015). The irrigation arrangements for paddy cultivation can only be made if the agricultural land used has adequate irrigation facilities and infrastructure. Therefore, the availability of irrigated land is very important to increase the area of paddy harvest and the paddy production itself.

The harvested area variable in the previous period (lag 1) indicated that the variable affected the paddy supply in East Java. The area of paddy harvest variable in East Java had a coefficient of 0.571, meaning that an increase in the previous harvest area of $1 \%$ can increase the area of paddy harvest in East Java at the present time of $0.571 \%$. The area of harvest in the previous period can be an incentive for farmers to cultivate paddy crops again in the current period. Increasingly better area of paddy harvest in the previous period becomes an important reason for farmers to expand the planting area, thus increasing the area of paddy harvest in the current period.

\section{ELASTICITY AND PADDY SUPPLY RESPONSE IN EAST JAVA}

Supply elasticity shows how much the supply response of a commodity to changes occurs from other variables used in the model (Nugroho et al., 2015).

In the short and long run, the elasticity of the paddy supply in East Java to the real price of unhulled rice is inelastic (Table 6). The value of paddy elasticity 
in the short run for the real price of unhulled rice was 0.1468 . This value means that if the real price of unhulled rice increases by $10 \%$, causing the paddy supply (paddy harvested area) to increase by $1.4680 \%$ in the short run. In the long run, the elasticity of the paddy supply in East Java to the real price of unhulled rice was 0.3420 , which means that every $10 \%$ increase in the real price of unhulled rice can cause the increase in the paddy supply in East Java by $3.4200 \%$.

TABLE 6 . PADDY SUPPLY ELASTICITY IN EAST JAVA

\begin{tabular}{lccr}
\hline Variables & $\begin{array}{r}\text { Short Run } \\
\text { Elasticity }\end{array}$ & $\begin{array}{r}\text { Co-efficient of } \\
\text { Adjustment }\end{array}$ & $\begin{array}{r}\text { Long Run } \\
\text { Elasticity }\end{array}$ \\
\hline Price of & 0.1468 & & 0.3420 \\
Unhulled rice & 0.7702 & 0.4293 & 1.7938 \\
Irrigation Area & 0.5707 & & 1.3291 \\
Harvest Area & & & \\
Lag 1 & Source: Secondary Data Analysis (2018)
\end{tabular}

Source: Secondary Data Analysis (2018)

The value of the short run or long run elasticity of the paddy supply in East Java was less than 1. The results indicate that paddy supply in East Java has a slow response to changes in real unhulled rice prices at the farmer level. The occurrence of real unhulled rice price increase was not followed by a rapid increase in the paddy supply in East Java. The slow response of the paddy supply in East Java approached by using the area of paddy harvesting on the real price of unhulled rice is due to high fluctuations in the real price of unhulled rice at the farmer level. The real price of unhulled rice in East Java is very fluctuating at the farmer level, causing higher risk that will be faced by farmers in carrying out paddy cultivation. Paddy farmers are mostly subsistence, they will always face risk and uncertainties, therefore farmers are forced not to prioritize the seeking for maximum profits, but trying to avoid failure by taking minimum risks (Suharyanto et al., 2015). The high risk faced by farmers means there is a greater likelihood of losses to be received by farmers (Lawalata et al., 2017). This can be a disincentive for farmers to increase paddy supply, so farmers will be reluctant to work on paddy crops. Price fluctuations that occur at the farmer level can be caused by an imbalance of market price information received by farmers with other market participants (Heriani et al., 2013). The occurrence of asymmetric market price information triggers the price at the farmer level to be much lower than the price at the consumer level.

The short run elasticity value of the paddy supply in East Java was estimated using the area of paddy harvest to the area of irrigated land of 0.7702 as shown in Table 6 . The value indicates that in the short run, an increase in irrigated area by $10 \%$ can increase the supply of paddy harvest area by $7.7020 \%$. The long run elasticity of supply of paddy harvest area in East Java was 1.7938. This value means that in the long run, the supply of paddy harvest area in East Java increased by $17.9380 \%$ every $10 \%$ increase in irrigated area. These results indicated that in the short run, the supply of paddy area in East Java to irrigated land was inelastic, but in the long run the supply of paddy harvest area to the irrigated area was elastic. This shows that in the short term, the supply of rice harvested area is unresponsive to the changes in the area of irrigated land, but in the long run the supply of rice harvested area is responsive to the changes in the area of irrigated land. In the short run, the paddy supply in East Java has a slow response to the changes in irrigated land area due to the development of irrigation facilities and time-consuming conditions, so that in the short run these variables cannot have a rapid effect on increasing paddy supply. However, the long run supply of paddy to irrigated areas has a rapid response because in the long run, the increase in irrigated area can increase the production and productivity of paddy crops (Muzdalifah, 2014) Higher paddy productivity has a positive impact on the increasing income of paddy farmers due to the increasingly efficient paddy farming that is run (Indah et al., 2015). This can be an incentive for paddy farmers in East Java to increase paddy supply.

It can also be seen in Table 6 that in the short run, the paddy supply in East Java was inelastic to the variable of area of harvested paddy lag 1 (previous period) with a value of elasticity of 0.5707 . This value means that in the short run, paddy supply increased by $5.707 \%$ everytime the area of first lag (the year before) increased by $10 \%$. A supply elasticity less than $10 \%$ indicates that the supply of paddy harvest area in East Java has a slow response to the increase or decrease in the area of harvest in lag 1 . However, in 
the long run the supply of paddy harvest area becomes responsive to increase or decrease the area of paddy harvest in lag 1 with the elasticity of 1.3291 . The value indicates that in the long run, the increase in paddy harvest area in lag 1 by $10 \%$ can lead to an increase in the area of paddy harvest of $13.2910 \%$. The paddy harvest area in East Java in lag 1 or at one year earlier can provide incentives for farmers to increase the area of harvest at the present time. The increase in harvest area from the previous year will motivate farmers to expand their cultivation area, thus stimulating the paddy harvest area supply in East Java to increase.

\section{POLICY IMPLICATIONS}

In this study there are some policy implications that can be applied from the analysis and discussion that has been done. The results showed that the variable of real price of unhulled rice, the area of irrigated land and the area of harvest of the previous year had a significant and positive effect on the paddy supply in East Java which was estimated using paddy harvest area. This shows that to increase the paddy supply in East Java, we need to increase the real price of unhulled rice at the farm level, the area of irrigated land and the area of paddy harvest in East Java in the previous year. In addition, the supply of paddy in East Java is more responsive to the changes in irrigated land area compared to the changes in real unhulled rice prices and harvested area of the previous year. The results could be a reference that paddy supply in East Java will increase faster if there is an increase in irrigated land area compared to an increase in real price of paddy at the farm level and an increase in the area of paddy in the previous year. However, the real price of unhulled rice at the farm level also needs to be increased even in a slow response because in the long run these variables will still have a positive impact on the paddy supply in East Java. In addition, the area of harvest in the previous year period also needs to be expanded. This is because these variables can contribute to an increasing supply of paddy in East Java in the long run.

\section{CONCLUSION}

The results show that there is a short-term balance adjustment to the long-term balance, but the results of the analysis show that the short-term to longterm adjustment for paddy supply in East Java takes a long time. The factor that significantly affects the paddy supply in the short-run in East Java estimated by using the area of paddy harvest is the real unhulled rice price at the farmer level, while in the long-run the factors that significantly affect the paddy supply are the real price of unhulled rice at the farm level, the area of irrigated land and the area of paddy harvest in the previous year. The real price of unhulled rice at the farm level is inelastic in both the short and long term, while the area of irrigated land and the area of paddy harvest in the previous year are inelastic in the short term, but elastic in the long term.

\section{ACKNOWLEDGMENT}

Thank you for the financial assistance of the educational scholarship from the Education Fund Management Institute (LPDP), which has helped writers financially to study economic of agriculture.

\section{REFERENCES}

Akanni, K. A. and Okeowo, T. A. (2011). Analysis of aggregate output supply response of selected food grains in Nigeria. Journal of Stored Products and Postharvest, 2(14), 266-278.

Akbar, R. A., Rusgiyono, A., \& Tarno. (2016). Analisis integrasi pasar bawang merah menggunakan metode Vector Error Correction Model (VECM) (Studi kasus: Harga bawang merah di Provinsi Jawa Tengah). Jurnal Gaussian, 5(4), 811-820.

Atmaja, M. A. J., Kencana, I. P. E. N., \& Gandhiadi, G. K. (2015). Analisis kointegrasi jumlah wisatawan, inflasi dan nilai tukar terhadap Produk Domestik Regional Bruto ( PDRB ) Povinsi Bali. E-Jurnal Matematika, 4(3), 8389.

Ayinde, O. E., Bessler, D. A., \& Oni, F. E. (2017) Analysis of supply and price risk on rice production in Nigeria. Journal of Agribusiness and Rural Development, 1(43), 17-24.

Ayu, M., \& Pramesty, P. (2016). Analisis penawaran padi gogo (oryza sativa) di Kabupaten Karanganyar. Jurnal Agrinis, 1(1), 21-44.

BPS. (2016). Survei pertanian produksi tanaman padi dan palawija di Indonesia. (A. Achmad \& J. 
Lumban, Eds.) (1st ed.). Jakarta: Badan Pusat Statistik Indonesia.

Choirina, V. N., Hartono, S., \& Suryantini, A. (2016). Supply response analysis of paddy in Kediri : Managerial implications. Jurnal Agro Ekonomi, 27(1), 107-120.

Denziana, A., Indrayenti, \& Fatah, F. (2014). Corporate financial performance effects of macro economic factors against stock return. British Journal of Psychiatry, 5(2), 17-40. https://doi.org/10.1192/bjp.205.1.76a

Dziwornu, R. K., \& Vitor, D. A. (2013). Stock exchange performance and economic growth in Ghana: Is there a causal link? Asian Journal of Empirical Research, 3(9), 1152-1165.

Ehirim, N. C., \& Owerri. (2017). Soybean supply response to price and non-price factors in Nigeria : Implications for food security. Asian Journal of Agricultural Extension, Economics \& Sociology, 15(3), 1-10. https://doi.org/10.9734/AJAEES/2017/8261

Garside, A. K., \& Asjari, H. Y. (2015). Simulasi ketersediaan beras di Jawa Timur. Jurnal Ilmiah Teknik Industri, 14(1), 47-58.

Gujarati, D. N. (2004). Basic Econometrics (4th ed.). New York: The McGraw-Hill Companies.

Heriani, N., Zakaria, W. A., \& Soelaiman, A. (2013). Analisis keuntungan dan risiko usahatani tomat di Kecamatan Sumberejo Kabupaten Tanggamus. Jiia, 1(2), 169-173.

Indah, L. S. M., Zakaria, W. A., \& Prasmatiwi, F. E. (2015). Analisis efisiensi produksi dan pendapatan usahatani padi sawah pada lahan irigasi teknis dan lahan tadah hujan di Kabupaten Lampung Selatan. Jiia, 3(3), 260267.

Khan, S. U., Faisal, M. A., UI Haq, Z., Fahad, S., Ali, G., Khan, A. A., \& Khan, I. (2018). Supply response of rice using time series data: Lessons from Khyber Pakhtunkhwa Province, Pakistan. Journal of the Saudi Society of Agricultural Sciences, 1-4 https://doi.org/10.1016/j.jssas.2018.03.001

Lawalata, M., Darwanto, D. H., \& Hartono, S. (2017). Risiko usahatani bawang merah di Kabupaten Bantul. Agrica (Jurnal Agribisnis Sumatera Utara), 10(1), 56-73. Retrieved from http://ojs.uma.ac.id/index.php/agrica

Muhammad, M. (2014). Kointegrasi dan estimasi ecm pada data time series. Jurnal Konvergensi, $4(1), 41-51$.

Muzdalifah. (2014). Pengaruh irigasi terhadap produksi usahatani padi sawah di Desa Sidera
Kecamatan Sigi Biromaru. Jurnal Agrotekbis, 2(1), 76-84.

Ngbede, Ochoche, S., Akintola, \& Olatunji, J. (2009). Co-integration and Error-Correction Modeling of agricultural output. A case of groundnut. Researcher, 1(6), 27-32.

Nugroho, A., Rahayu, E. S., \& Ani, S. W. (2015) Respon penawaran salak (Salacca zalacca) di Kota Salatiga. AGRISTA, 3(2), 25-35.

Obayelu, A. E., \& Sheu Salau, A. (2010). Agricultural response to prices and exchange rate in Nigeria: Application of co-integration and Vector Error Correction Model (VECM). J Agri Sci, 1(2), 73-81.

Okon, B., \& Sunday, A. (2014). Supply response of selected agricultural export commodities in Nigeria. Journal of Economics and Sustainable Development, 5(5), 2222-1700. Retrieved from www.iiste.org

Partini, Tarumun, S., \& Tety, E. (2013). Analisis faktorfaktor yang mempengaruhi penawaran dan permintaan beras di Provinsi Riau. Pekbis Jurnal, 5(3), 170-178.

Purbiyanti, E., Muhammad, Y., \& Indri, J. (2017). Konversi lahan sawah di Indonesia dan pengaruhnya terhadap kebijakan Harga Pembelian Pemerintah ( HPP) gabah/beras Jurnal Manajemen \& Agribisnis, 14(3), 209217.

Rahji, M. A. Y., \& Adewumi, M. O. (2008). Market supply response and demand for local rice in Nigeria: Implications for self-sufficiency policy. Journal of Central European Agriculture, 9(3), 567-574.

Shahzad, M., Jan, A. U., Ali, S., \& Ullah, R. (2018). Supply response analysis of tobacco growers in Khyber Pakhtunkhwa: An ARDL approach. Field Crops Research, 218(September 2017)، 195-200. https://doi.org/10.1016/j.fcr.2018.01.004

Suharyanto, S., Rinaldy, J., \& Ngurah Arya, N. (2015). Analisis risiko produksi usahatani padi sawah. AGRARIS: Journal of Agribusiness and Rural Development Research, 1(2), 70-77. https://doi.org/10.18196/agr.1210

Widodo, A. S., \& Wulandari, R. (2016). Analisis pola konsumsi dan tingkat kerawanan pangan petani lahan kering di Kabupaten Gunungkidul (Studi kasus di Desa Giritirto, Kecamatan Purwosari, Gunungkidul). AGRARIS: Journal of Agribusiness and Rural Development Research, 2(2), 161-167. https://doi.org/10.18196/agr.2237 
AGRARIS: Journal of Agribusiness and Rural Development Research

Yanti, D., \& Pratama, F. N. (2015). Pendayagunaan irigasi air tanah menunjang budidaya pertanian secara produktif pada lahan tadah hujan. Jurnal Teknologi Pertanian Andalas, 19(2), 10-17. 